\title{
STUDIES ON THE PATHOGENESIS OF CHICKEN INFECTIOUS ANAEMIA VIRUS INFECTION IN SIX-WEEK-OLD SPF CHICKENS
}

\author{
Cs. N. DrÉN ${ }^{1 *}$, A. KAnt ${ }^{2}$, D. J. VAn RoOZelaAR ${ }^{2}$, L. HARTOG $^{2}$, M. H. M. NoteborN ${ }^{3}$ \\ and G. $\mathrm{KOCH}^{2}$ \\ ${ }^{1}$ Veterinary Medical Research Institute, Hungarian Academy of Sciences, \\ H-1581 Budapest, P.O. Box 18, Hungary; ${ }^{2}$ DLO Institute of Animal Science and Health, \\ Lelystad, The Netherlands; ${ }^{3}$ Laboratory for Molecular Carcinogenesis, \\ Leiden University, Leiden, The Netherlands
}

(Received June 30, 2000; accepted October 17, 2000)

The pathogenesis of chicken infectious anaemia virus (CAV) infection was studied in 6-week-old and one-day-old SPF chickens inoculated intramuscularly with graded doses of Cux-1 strain $\left(10^{6}-10^{2} \mathrm{TCID}_{50} /\right.$ chicken $)$. Viraemia, virus shedding, development of virus neutralizing (VN) antibodies and CAV distribution in the thymus were studied by virus isolation, polymerase chain reaction (PCR), immunocytochemistry (IP) and in situ hybridization until postinfection day (PID) 28. In 6-week-old chickens infected with high doses of CAV, viraemia and VN antibodies could be detected 4 PID and onward without virus shedding or contact transmission to sentinel birds. However, virus shedding and contact transmission were demonstrated in one-day-old infected chickens. In the 6-weekold groups infected with lower doses, VN antibodies developed by PID 14, transient viraemia and virus shedding were detected. The thymus cortex of all 1-dayold inoculated chickens stained with VP3-specific mAb. Cells with positive in situ hybridization signal were fewer and scattered throughout the thymus tissue of the one-day-old inoculated chickens as compared to IP-positive cells. These results suggest that early immune response induced by high doses of CAV in 6-week-old chickens curtails viral replication and prevents virus shedding.

Key words: Chicken infectious anaemia virus, PCR, immunosuppression, pathogenesis, epidemiology

Chicken infectious anaemia virus (CAV) is one of the most important immunosuppressive viruses of neonatal chickens (Bülow and Schat, 1997). In addition to the domestic chicken, Japanese quail could also be considered a natural host of CAV (Farkas et al., 1998), which has not yet been placed into any known virus family (Noteborn and Koch, 1995; Bülow and Schat, 1997). The disease has been extensively studied (Bülow and Schat, 1997), and characterized by severe anaemia, pancytopenia, haemorrhages throughout of the body and general-

*E-mail: dren@novell.vmri.hu; Fax: +36 (1) 467-4076 
DRÉN et al.

ized lymphoid atrophy with the sequel of transient, but severe immunosuppression (Adair, 2000). The severity of the clinical disease depends on several factors, including virus dose (McNulty et al., 1990) and age at infection (Yuasa et al., 1979). It is believed that the development of age resistance is strongly associated with the maturation of the immune system (Yuasa et al., 1983). Chickens without maternally derived antibody (MDA) infected before this point of time succumb to severe clinical disease, but those having a fully competent immune system survive the infection without showing any clinical signs of infection. However, irrespective of the age at infection, immunosuppression develops, which increases the susceptibility of the chickens to secondary viral, bacterial and fungal infections, and may decrease the efficacy of vaccines (Adair, 2000). Moreover, other immunosuppressive factors could increase the pathogenicity of CAV. Therefore, the ubiquitous CAV is considered to be frequently involved in the pathogenesis of several neonatal diseases and it may be responsible for several vaccine breaks (Bülow and Schat, 1997). Although chickens with maternally derived antibodies (MDA) are fully protected against the clinical disease, the subclinical form of the infection is poorly understood (Yuasa et al., 1983; Adair, 2000; Bülow and Schat, 1997). Here we report some of our results on the pathogenesis of CAV infection in 6-week-old SPF chickens. Development of viraemia and virus shedding have been followed up and compared to the development of virus neutralizing antibodies using bioassays and hot-start polymerase chain reaction (PCR), respectively.

\section{Materials and methods}

\section{Cell cultures and virus}

Chicken T-cell line MDCC-MSB1 cells (MSB1), transformed by Marek's disease virus (Akiyama and Kato, 1974), were cultured according to the published procedure (Bülow et al., 1985). MSB1 cells were infected with the Cuxhaven-1 isolate of CAV (Bülow et al., 1985) with a multiplicity of infection of 1 $50 \%$ tissue culture infectious dose $\left(\mathrm{TCID}_{50}\right)$ per cell. Cell-free CAV was harvested $48 \mathrm{~h}$ after infection by centrifugation of infected MSB1 cells, the supernatant was chloroform treated, aliquoted and stored at $-75^{\circ} \mathrm{C}$. The titre was determined by standard virus titration in 96-well tissue culture plates (G. F. de Boer, personal communication). CAV isolation from different samples was also done in MSB1 cells (Yuasa et al., 1983).

\section{Virus neutralization assay}

The titre of virus neutralizing (VN) antibodies in serum samples collected from different groups of chickens was determined according to Koch et al. (1995). 


\section{Immunocytochemistry (IHC)}

Cryostat sections of $8 \mu \mathrm{m}$ were mounted onto glass slides, air-dried and fixed in acetone for $10 \mathrm{~min}$ at room temperature. Sections were incubated with monoclonal antibodies developed against VP1, 2 and 3 proteins of Cux-1 (Noteborn et al., 1991). After $1 \mathrm{~h}$ of incubation and three cycles of washing, they were incubated with peroxidase-labelled goat anti-mouse Ig (Dakopatts, Denmark) for $30 \mathrm{~min}$, followed by three washing steps. Peroxidase activity was detected with 3,3'-diaminobenzidine tetrahydrochloride (DAB, Sigma, USA) solution in $0.05 \mathrm{M}$ Tris- $\mathrm{HCl}$ buffer ( $\mathrm{pH}$ 7.6) containing $0.01 \% \mathrm{H}_{2} \mathrm{O}_{2}$. After development of the brown colour, slides were rinsed in PBS and mounted in Gurr Aquamount Mountant (BDH, UK).

\section{Polymerase chain reaction (PCR)}

The DNA templates for PCR were extracted from different samples according to Boom et al. (1990). In brief, cells and/or tissues were incubated for $2 \mathrm{~h}$ at room temperature (RT) in lysis buffer containing guanidinium thiocyanate $(\mathrm{GuSCN})$, which was followed by centrifugation in an Eppendorf microfuge. The supernatant was transferred into another tube containing $40 \mu \mathrm{l}$ diatom, derived from fossilized unicellular algae, which has nucleic acid binding properties. After 10 min of incubation at RT, the tubes were vortexed, centrifuged in an Eppendorf centrifuge and the diatom-nucleic acid complex was washed twice with washing buffer, twice with $70 \%$ ethanol, and once with acetone. After removal of the acetone, the tubes were dried in a heat block for $10 \mathrm{~min}$ and after addition of the elution buffer $(1 \times$ PCR buffer $)$ they were incubated at $56{ }^{\circ} \mathrm{C}$ for $10 \mathrm{~min}$. The tubes were vortexed briefly, centrifuged in an Eppendorf centrifuge and the supernatant was used in the PCR reaction. PCR assays were carried out as described by Drén et al. (1994). Synthetic oligonucleotides were used as amplification primers designated CAV-1 (positions 349 to $367 \mathrm{nt}$ ) and CAV-2 (positions 535 to $517 \mathrm{nt}$ ). The oligonucleotide CAV-3 (positions 415 to $433 \mathrm{nt}$ ) was used as a internal probe. The primers and probe were selected and synthesized on the basis of the published sequence of CAV-CUX-1 (Noteborn et al., 1991). The primer set CAV-1/CAV-2 amplified a fragment of $186 \mathrm{bp}$. Amplifications were performed in $50 \mu \mathrm{l}$ reaction mixture containing 1 or $5 \mu 1$ DNA template as described by Drén et al. (1994). In brief, the mixtures were first denatured at $95{ }^{\circ} \mathrm{C}$ for 2 min (hot start) and then amplified by 30 successive cycles of denaturation at $95{ }^{\circ} \mathrm{C}$ for $1 \mathrm{~min}$, annealing at $55{ }^{\circ} \mathrm{C}$ for $1 \mathrm{~min}$, followed by an extension at $72{ }^{\circ} \mathrm{C}$ for $1 \mathrm{~min}$, and an overnight incubation at $+4{ }^{\circ} \mathrm{C}$. After completion of amplification the tubes were centrifuged in an Eppendorf centrifuge, $10 \mu l$ loading buffer ( $30 \%$ glycerol in $\mathrm{H}_{2} \mathrm{O}, 0.5 \mathrm{mg} / \mathrm{ml}$ xylene cyanol, $0.5 \mathrm{mg} / \mathrm{ml}$ bromophenol blue) was mixed with the amplified product which was resolved by $1.5 \%$ agarose gel electrophoresis and visualized by ethidium bromide staining under UV fluo- 
DRÉN et al.

rescence. HimfI DNA fragments of pUC18 DNA were used as DNA marker. Southern blot hybridization was done as described by Drén et al. (1994) using Hybond-N+ (Amersham, UK) and capillary blotting. CAV-3 oligonucleotide probe was end labelled with T4 polynucleotide kinase with $\left[\gamma_{-}{ }^{32} \mathrm{P}\right] \mathrm{ATP}$ and was used for hybridization overnight at $42{ }^{\circ} \mathrm{C}$. The activity of the probe varied between $1.7 \times 10^{4}$ and $7.5 \times 10^{4} \mathrm{cpm} / 1 \mu \mathrm{l}$. After hybridization the membrane was washed once in $5 \times \mathrm{SSC}-0.1 \% \mathrm{SDS}$ at $42{ }^{\circ} \mathrm{C}$ for $15 \mathrm{~min}$, twice in $2 \times \mathrm{SSC}-0.1 \%$ SDS for 15 min at $42{ }^{\circ} \mathrm{C}$ and $55^{\circ} \mathrm{C}$, respectively, and once in $1 \times \mathrm{SSC}-0.1 \%$ SDS at $55^{\circ} \mathrm{C}$ for $15 \mathrm{~min}$. Filter was wrapped in SaranWrap and autoradiography was carried out overnight at $-75^{\circ} \mathrm{C}$ using Kodak X-Omat AR X-ray film.

In situ hybridization

For studying the tissue and/or cell distribution of CAV in different organs the hybridization technique published by Allan et al. (1993) was used with some modification. In brief, Cux-1 infected and uninfected MSB1 cell suspension was cytocentrifuged onto SuperFrost*/Plus slides (Menzel-Glaser, Germany), fixed in $4 \%$ neutral formalin and used as internal control for the in situ hybridization experiment. Alternatively, parallel slides with the same source of deposited cells were fixed in acetone and stained by IP technique using $\mathrm{mAbs}$ directed against VP1, VP2 and VP3 proteins of CAV. Tissue sections were cut $(4 \mu \mathrm{m})$ onto SuperFrost*/Plus slides, dewaxed, rehydrated, briefly treated with $0.2 \mathrm{~N} \mathrm{HCl}$ at RT, washed twice in $2 \times \mathrm{SSC}$ containing $5 \mathrm{mM}$ EDTA at $50^{\circ} \mathrm{C}$, followed by drying at $95{ }^{\circ} \mathrm{C}$ for $5 \mathrm{~min}$. Sections were then digested at $37{ }^{\circ} \mathrm{C}$ for $15 \mathrm{~min}$ with proteinase $\mathrm{K}$, and washed in $0.2 \%(\mathrm{v} / \mathrm{v})$ glycine-PBS. After prehybridization for $15 \mathrm{~min}$ at $37^{\circ} \mathrm{C}$ the sections were twice washed in PBS and dried on heat block at $95{ }^{\circ} \mathrm{C}$. For hybridization linearized EcoRI pCAV was used (Noteborn et al., 1991), which was labelled with digoxigenin-11-dUPT (DIG-probe) using Nonradioactive DNA Labelling and Detection Kit (Boehringer Mannheim). Hybridization with the DIG-probe started at $95{ }^{\circ} \mathrm{C}$ for $5 \mathrm{~min}$ and continued at $37^{\circ} \mathrm{C}$ overnight in humidified box. Sections were washed in $6 \times \mathrm{SSC}$ at $42^{\circ} \mathrm{C}$, twice in $2 \times$ $\mathrm{SSC}$ at RT and twice in $0.2 \times \mathrm{SSC}$ at $50^{\circ} \mathrm{C}$. For the detection of DIG-probe, the manufacturer's anti-digoxigenin-alkaline phosphatase conjugate was incubated for $30 \mathrm{~min}$ at RT, followed by washing $2 \times 15 \mathrm{~min}$ with $100 \mathrm{mM}$ Tris- $\mathrm{HCl}$ containing $150 \mathrm{mM} \mathrm{NaCl}, \mathrm{pH} 7.5$. The DIG-probe-conjugate location was visualized with nitroblue tetrazolium containing 5-bromo-4-chloro-3-indolylphosphate (NBT/BCIP) as substrate. Sections were then washed for $5 \mathrm{~min}$ at RT in $10 \mathrm{mM}$ Tris- $\mathrm{HCl}$ containing $1 \mathrm{mM}$ EDTA, pH 8.0. Slides were mounted in Aqua Mount mountant (BDH). 


\section{Experimental design}

In the first experiment 87 six-week-old and 14 one-day-old SPF chickens were divided into 7 groups and placed into separate Horsfall-Bauer type isolators. Ten 6-week-old chickens in Group 1 were inoculated intramuscularly (i.m.) with $10^{6} \mathrm{TCID}_{50}$ of Cux-1 strain $(0.5 \mathrm{ml} /$ chicken $)$ and 10 chickens in the same isolator were left uninoculated and served as contact controls. Chickens of Groups 2, 3, 4 and 5 were inoculated with $10^{5}, 10^{4}, 10^{3}$ and $10^{2} \operatorname{TCID}_{50}$ of the same virus batch, respectively. Chickens in Group 6 were inoculated with uninfected MSB1 tissue culture medium, and in Group 7, fourteen 1-day-old chickens were inoculated with $10^{6} \mathrm{TCID}_{50}$ of Cux-1. Heparinized whole blood cells (WB) and cloacal swab (CS) samples were collected from each chicken at different postinoculation days (PID) as indicated in Tables 1, 2 and 3. Blood cells of $100 \mu \mathrm{lWB}$ were deposited by low-speed centrifugation, washed 3 times in PBS, resuspended in $100 \mu \mathrm{PBS}$, aliquoted in $50 \mu \mathrm{l}$ and stored frozen at $-75^{\circ} \mathrm{C}$ for later use. Plasma samples were saved for the detection of anti-CAV antibodies using the standard micro-neutralization method. The tissue distribution of CAV was studied by IP staining of cryostat sections of organ samples collected at PID 6 from Group 1 inoculated and contact-exposed 6-week-old chickens. Positive control organ samples were collected from chickens of Group 7 inoculated at one day of age and the negative control samples were derived from Group 6 medium inoculated chickens. Organ samples were divided into three parts and treated as follows: (a) snap frozen in liquid nitrogen in Cryo-M bed and stored frozen at $-70{ }^{\circ} \mathrm{C}$ for IP examination; (b) stored frozen at $-70{ }^{\circ} \mathrm{C}$ for DNA extraction and PCR analysis; (c) fixed in $4 \%$ buffered neutral formalin overnight and embedded in paraffin for in situ hybridization and/or for routine histological examination.

In the second experiment, 1-day-old SPF chickens were inoculated i.m. with $10^{6} \mathrm{TCID}_{50}$ of Cux-1 strain. Thirty inoculated and 30 contact chickens were placed into an isolation room operating under positive pressure and supplied with filtered air. Cloacal swabs were collected from each bird at 4, 5, 6, 7 and 28 days after infection. Virus shedding in the faeces was determined as described previously.

\section{Results}

Group 1 of 6-week-old chickens inoculated with a high dose of CAV developed viraemia (WB) and virus neutralizing (VN) antibodies by PID 4 and 6 (Tables 1 and 2). At PID 4 and 6 CAV could not be detected in cloacal swab (CS) samples using tissue culture (Table 1) or PCR (data not shown) techniques. However, thymuses collected from Group 7 at or before PID 6 were positive by PCR (Fig. 1), but those derived from Group 1 were negative (Fig. 1). VN antibodies were either present (Groups 2 and 3) or undetectable (Groups 4 and 5) at PID 4 in plasma samples from chickens which were inoculated with less than $10^{4}$ 
TCID $_{50}$. By PID 14, however, most of the plasmas from the low-dose inoculated groups had high titre of $\mathrm{VN}$ antibodies (Tables 1 and 2), which did not change significantly at later time points, i.e., PID 21 and 28. The number of chickens with CAV in their blood, i.e., viraemia, gradually decreased (Table 1), but a few plasma samples were still positive at PID 28 (Table 1) even in the presence of a high titre of VN antibodies (Table 2, Group 5). At PID 14 there were very few chickens in Groups 3 and 5 (Table 1) which were still shedding CAV into the faeces, but none of them were positive at the following two sampling times, i.e., PID 21 and 28 (Table 1). The infectious status of Groups 2 through 5 has not yet been tested before PID 14 as far as viraemia and faecal virus shedding are concerned, with the exception of Group 5. Three out of five cloacal swabs from the latter group were positive by PCR (Fig. 2). Chickens of this group were not tested for viraemia and faecal virus shedding at PID 4 and 6. At days 21 and 28 after infection, the antibody titre did not change significantly (Table 2) and some of the chickens were still viraemic even at PID 28 (Table 1). At those time-points CAV could not be detected in the faeces (Table 1).

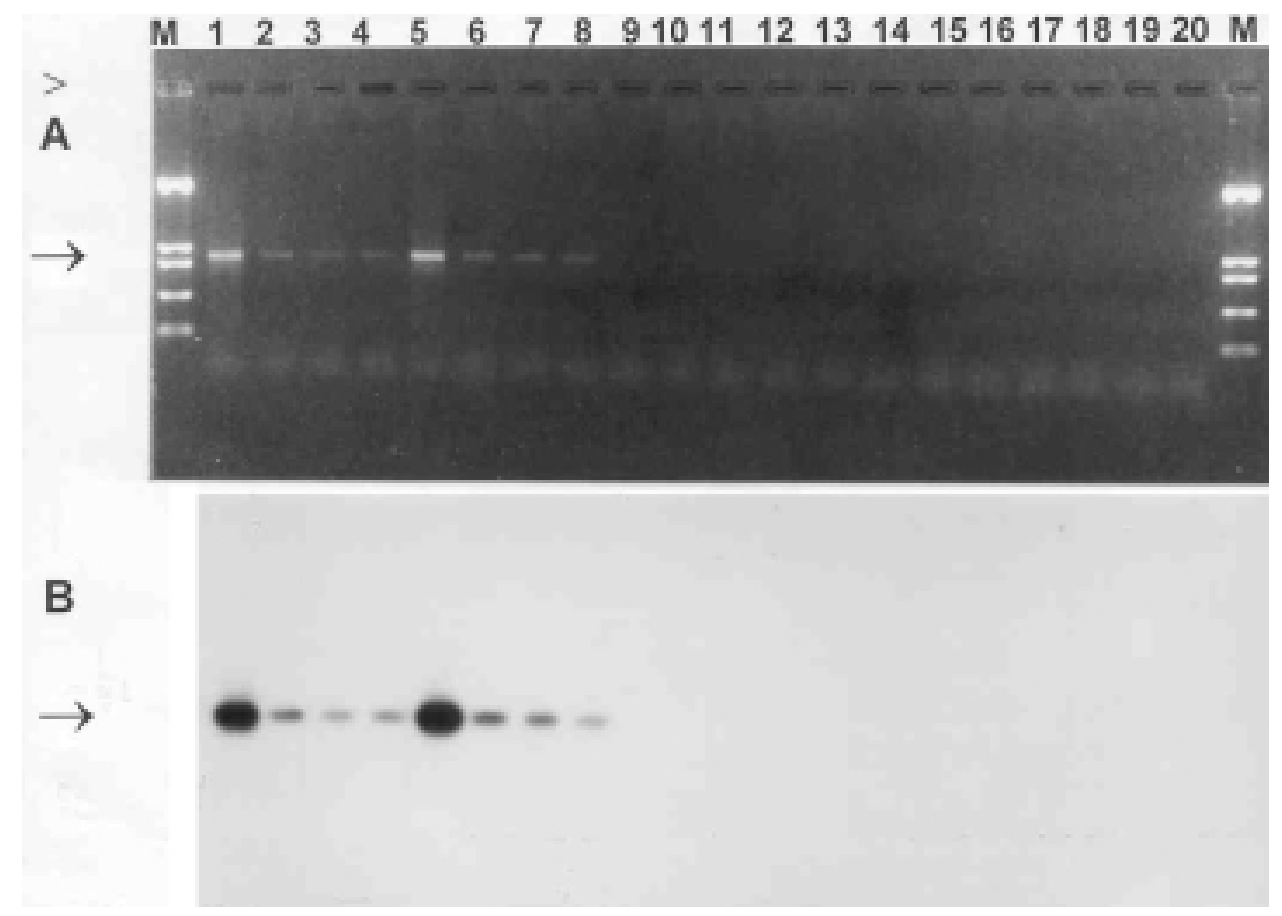

Fig. 1. DNA samples from thymuses of Group 7 (lanes 1-8) and Group 1 (lanes 10-19) were amplified and analysed on ethidium bromide stained $1.5 \%$ agarose gel (A) and Southern blot hybridization with ${ }^{32} \mathrm{P}$-labelled CAV-3 probe (B). Lanes number 9 and 20 loaded with samples from no-DNA template tubes. $\mathrm{M}=\mathrm{DNA}$ marker (pUC18/HinfI fragments). $\rightarrow=186$ bp product; $>=$ slots 


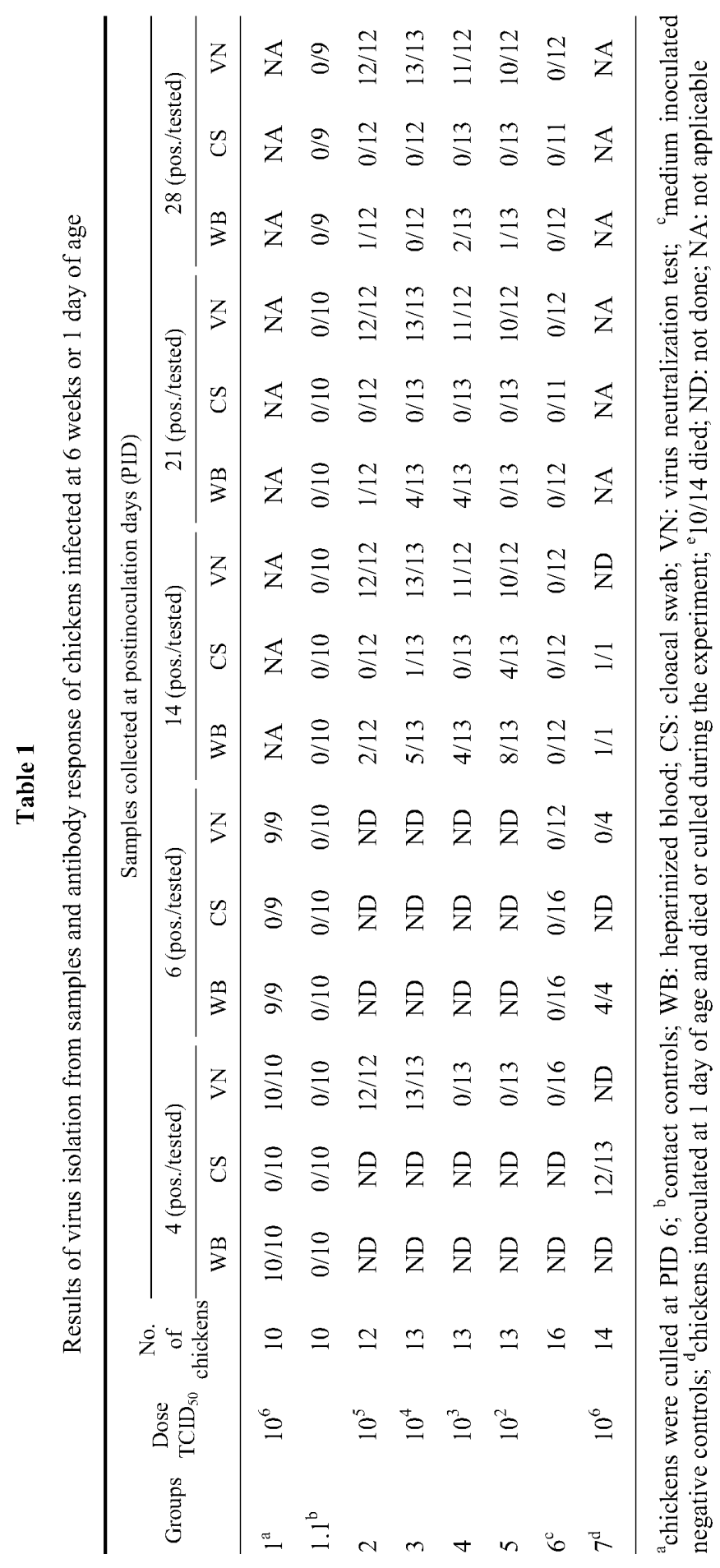




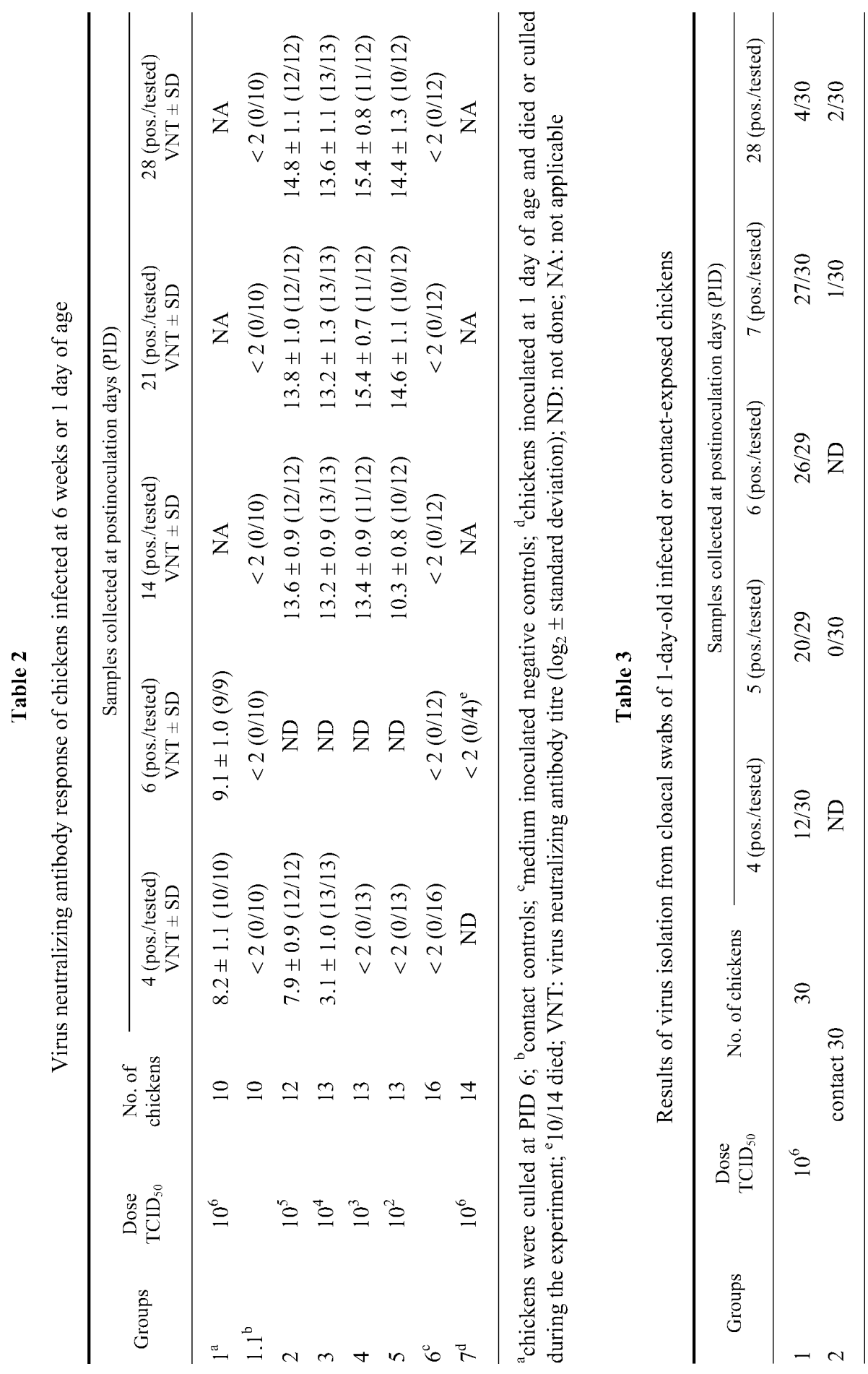


In immunologically immature 1-day-old chickens infected with a high dose of CAV, viral shedding was detected as early as PID 4 both by virus isolation (Group 7 in Table 1; Group 1 in Table 3) and PCR (Fig. 2). Viral shedding in the second experiment lasted till PID 28, i.e. till the termination of the experiment (Group 1 in Table 3).

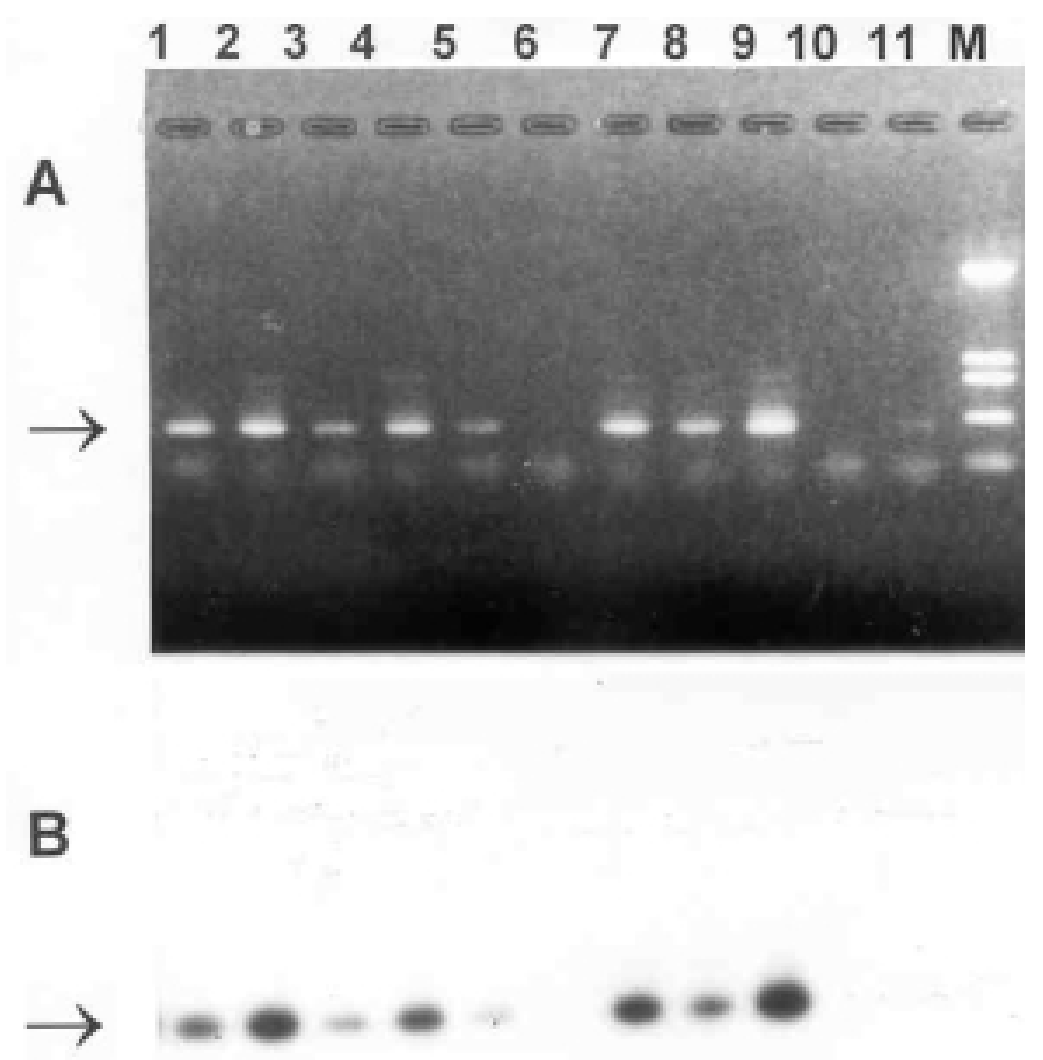

Fig. 2. DNA samples from cloacal swabs collected 4 days after inoculation from Group 7 (lanes 1-5) and Group 5 (lanes 7-11) were amplified and analysed on 1.5\% agarose gel stained with ethidium bromide (A) or by Southern blot hybridization with ${ }^{32} \mathrm{P}$-labelled CAV-3 probe (B). $\mathrm{M}=$ DNA marker (pUC18/HinfI fragments); Lane $6=$ no DNA template;

$\rightarrow=186$ bp product; $>=$ slots

In the first experiment 10 out of 14 chickens of Group 7 died by PID 6 (Table 1), but none of them died in the second experiment. We do not have any meaningful explanation for this discrepancy. In the first experiment $92 \%$ of Group 7 chickens were shedding virus into the faeces at PID 4, and contrary to the high-dose groups, no VN antibody response was detected at PID 6 (Table 1). In the second experiment the percentage of shedders among infected chickens 
DRÉN et al.

(Group 1, Table 3) was $90 \%$ by PID 7 and dropped to $13 \%$ by PID 28. Part of the in-contact 1-day-old chickens became infected by PID 7 as demonstrated by virus isolation from the faeces (Table 3 ).

\section{In situ hybridization}

According to some preliminary results, specific hybridization was present in thymus sections collected from Group 7 chickens of the first experiment (Fig. 3). There was no hybridization signal on thymus sections collected from uninoculated chickens. Likewise, positive hybridization was present on Cux-1 infected MSB1 cells but no signal was present on uninfected MSB1 cells (Fig. 4).
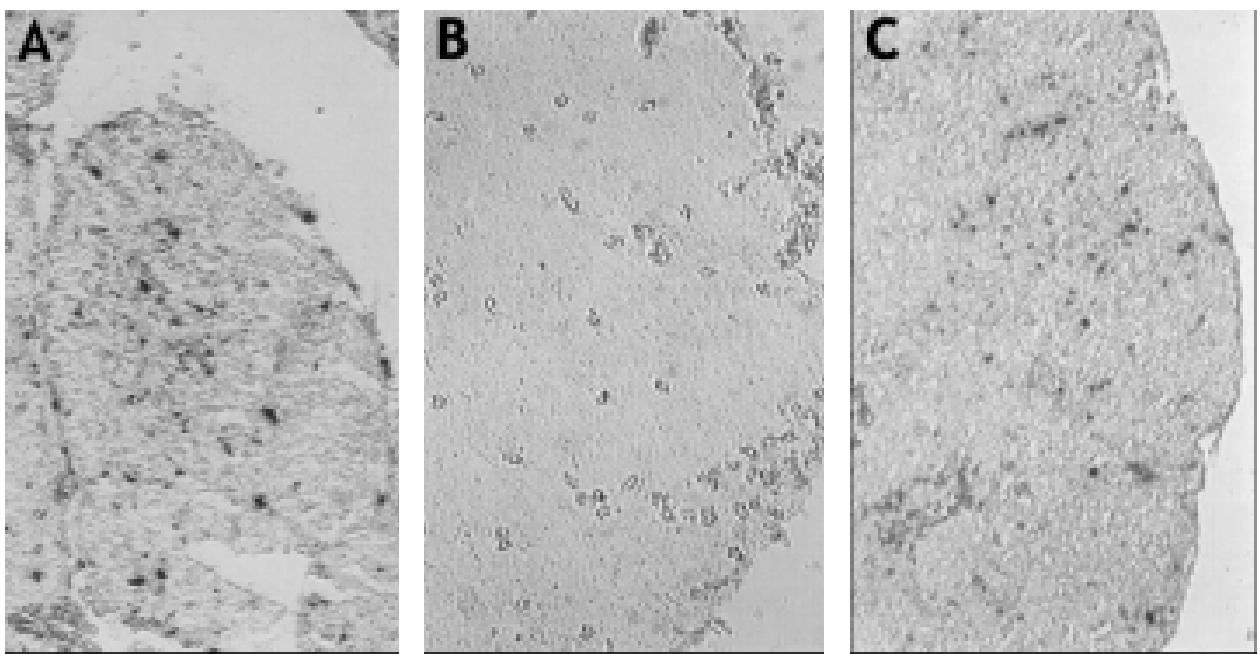

Fig. 3. In situ hybridization with DIG-labelled EcoRI-CAV probe of thymus sections from Group 7 chickens exterminated 6 days after infection. Few positive signals scattered over the sections

(A and C). There was no hybridization signal on the thymus section prepared from an uninfected chicken (B)

\section{Discussion}

Six-week-old chickens inoculated with a high dose of CAV developed both viraemia (Table 1) and moderately high titre of VN antibodies (Table 2) by PID 4. However, virus shedding into the faces could not be detected by virus isolation (Table 1). Group 1 chickens were exterminated at PID 6 for collection of organ samples for the detection of CAV distribution in various organs, which tests have not yet been completed. The contact-exposed group (Group 1.1) of this experiment remained negative by all criteria used for the detection of CAV (Table 1). These findings substantiate the proposal of the present and other authors 
(Yuasa et al., 1983) that latent virus carrier condition without virus shedding does exist, at least under experimental conditions. The interpretation of this latent carrier state on the basis of early immune response is very likely. This conclusion is substantiated by the findings obtained in Group 2 and partly in Group 3 chickens (Tables 1 and 2), indicating that there is a negative correlation between the development of high-titre $\mathrm{VN}$ antibodies and virus shedding, which is an extension of the data of others (Yuasa et al., 1983). This phenomenon might be the reason why the currently used vaccines should be administered several weeks before the point of lay (Vielitz et al., 1987) in order to prevent vertical transmission. The data of the other two six-week-old groups indicate that in the presence of high-titre VN antibodies at PID 14 (Table 2), 30 to $61 \%$ of the chickens of Groups 4 and 5, respectively, were viraemic (Table 1) and even $30 \%$ of the chickens of Group 5 were virus shedders (Table 1).

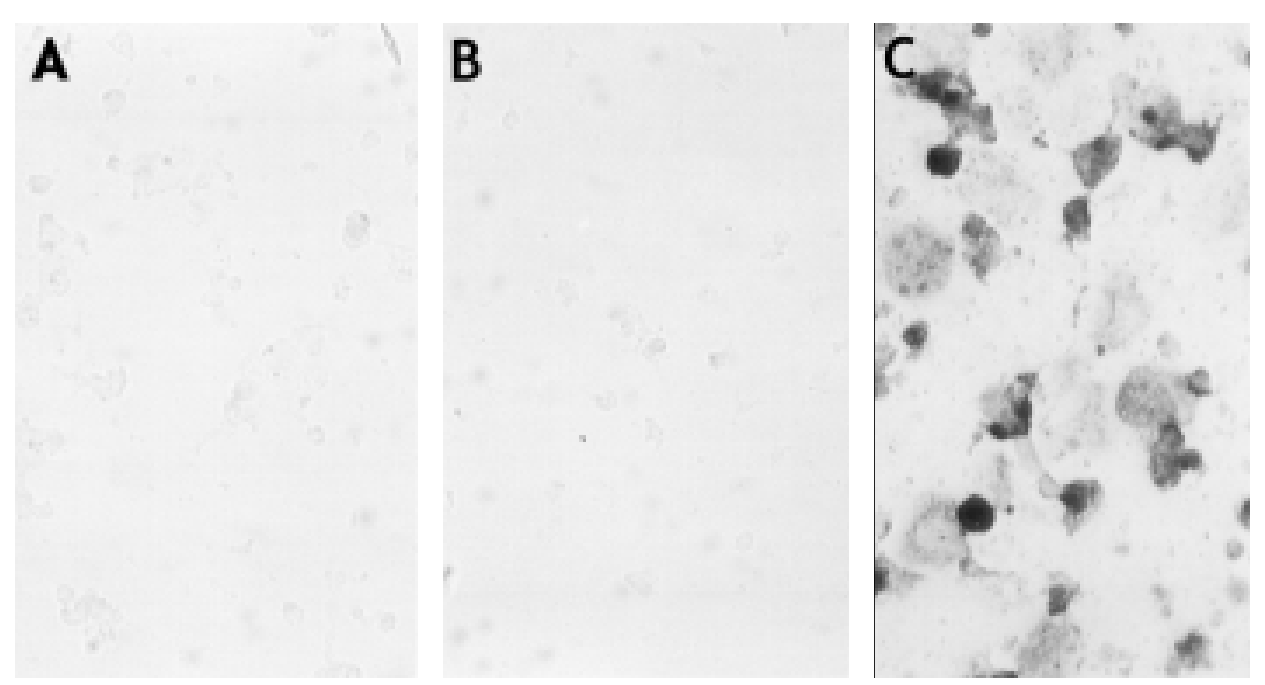

Fig. 4. In situ hybridization with DIG-labelled EcoRI-CAV probe of Cux-1 infected (C) and uninfected MSB1 cells (A). DIG-labelled probe was omitted from the reaction (B)

Despite the fact that just a few samples were tested by the hot-start PCR (Figs 1 and 2), in view of its excellent correlation with the labour-intensive and time-consuming virus isolation technique, it should be the method of choice in studies of CAV pathogenesis.

In situ hybridization depicted infected thymus cells of one-day-old infected chickens and CAV-infected MSB1 cells. This was comparable to the number of cells that were stained positively by mAbs against VP1, 2 and 3 proteins. Further experiments are needed to elucidate the correlation of the two techniques. In our hands, the number of positive cells, both in the thymuses and 
DRÉN et al.

in the infected MSB1 cells, were lower than the number stained positively by IP staining with mAbs. Moreover, the tissue distribution of positive cells in the thymus after hybridization was different from that observed after IP staining of the same thymus sections (data not shown). While after IP staining positive cells were located almost exclusively in the thymic cortex, the cells showing positive in situ hybridization signal were scattered throughout the thymus tissue (Fig. 3). The dissimilar results obtained after IP staining and in situ hybridization need further studies. This means that further validation effort is very much warranted in order to study the tissue distribution and target cell specificity of CAV.

In conclusion, it seems that in immunologically mature chickens infected with a very high dose of CAV (Group 1) latent infection takes place, and the chickens became viraemic shortly after infection and produced VN antibodies (mean \pm SD $\log _{2}: 8.2 \pm 1.1$ at PID 4 but no shedding was detected in the faeces. Chickens which were in contact (Group 1.1) with infected chickens (Group 1) for 6 days remained non-infected. In 6-week-old chickens infected with a lower dose (Groups 3 and 5), the latent infection was associated with both early immune response and transient virus shedding into the faeces; thus, these chickens are a potential source of horizontal virus transmission.

\section{References}

Adair, B. M. (2000): Immunopathogenesis of chicken anemia virus infection. Dev. Comp. Immunol. 24, 247-255.

Akiyama, Y. and Kato, S. (1974): Two cell lines from lymphomas of Marek's disease. Biken J. 17, 105-117.

Allan, G. M., Smyth, J. A., Todd, D. and McNulty, M. S. (1993): In situ hybridization for the detection of chicken anaemia virus in formalin-fixed, paraffin-embedded sections. Avian Dis. 37, 177-182.

Boom, R., Sol, C. J. A., Salimans, M. M. M., Jansen, C. L., Wertheim-van Dillen, P. M. E. and van der Noordaa, J. (1990): Rapid and simple method for purification of nucleic acids. J. Clin. Microbiol. 28, 495-503.

Bülow, V. v. and Schat, K. A. (1997): Chicken infectious anemia. In: Calnek, B. W. (ed.) Diseases of Poultry. 9th edition. Iowa State University Press, Ames, Iowa, pp. 739-756.

Bülow, V. v., Fuchs, B. and Bertram, M. (1985): Untersuchungen über den Erreger der infektiosen Anämie bei Hühnerküken (CAA) in vitro: Vermehrung, Titration, Serumneutralizationstest und indirekt Immunfluoreszenztest. Zbl. Vet-med. B 32, 679-693.

Drén, Cs. N., Koch, G., Kant, A., Verschueren, C. A. J., van der Eb, A. J. and Noteborn, M. H. M. (1994): A hot start PCR for the laboratory diagnosis of CAV. In: Kaleta, E. F. (ed.) Proceedings of the International Symposium on Infectious Bursal Disease and Chicken Infectious Anaemia. Rauischholzhausen, Germany, pp. 413-420.

Farkas, T., Maeda, K., Sugiura, H., Kai, K., Hirai, K., Otsuki, K. and Hayashi, T. (1998): A serological survey of chickens, Japanese quail, pigeon, ducks and crows for antibodies to chicken anaemia virus (CAV) in Japan. Avian Pathol. 27, 316-320.

Koch, G., van Roozelaar, D. J., Verschueren, C. A. J., van der Eb, A. J. and Noteborn, M. H. M. (1995): Immunogenic and protective properties of chicken anaemia virus proteins expressed by baculovirus. Vaccine 13, 763-770. 
McNulty, M. S., Connor, T. J. and McNeilly, F. (1990): Influence of virus dose on experimental anaemia due to chicken anaemia agent. Avian Pathol. 19, 167-171.

Noteborn, M. H. M. and Koch, G. (1995): Chicken anaemia virus infection: molecular basis of pathogenicity. Avian Pathol. 24, 11-31.

Noteborn, M. H. M., de Boer, G. F., van Roozelaar, D. J., Karreman, C., Kranenburg, O., Vos, J. G., Jeurissen, S. H. M., Hoeben, R. C., Zantema, A., Koch, G., van Ormondt, H. and van der Eb, A. J. (1991): Characterization of cloned chicken anemia virus DNA that contain all elements for the infectious replication cycle. J. Virol. 65, 3131-3139.

Vielitz, E., von Bülow, V., Landgraf, H. and Conrad, C. (1987): Anemia in broilers - development of a vaccine for breeder stock. Zbl. Vet.-Med. B 34, 553-557.

Yuasa, N., Taniguchi, T. and Yoshida, I. (1979): Isolation and some characteristics of an agent inducing anemia in chicks. Avian Dis. 23, 366-385.

Yuasa, N., Taniguchi, M., Goda, M., Shibatani, M., Imada, T. and Hihara, H. (1983): Isolation of chicken anemia agent with MDCC-MSB1 cells from chickens in the field. Natl. Inst. Anim. Health Q. 23, 75-77. 